\title{
Evidence for long residence times of rhyolitic magma in the Long Valley magmatic system: the isotopic record in precaldera lavas of Glass Mountain
}

\author{
A.N. Halliday ${ }^{1,3}$, G.A. Mahood ${ }^{1,2}$, P. Holden ${ }^{1, *}$, J.M. Metz ${ }^{2, * *}$, T.J. Dempster ${ }^{3}$ \\ and J.P. Davidson ${ }^{1, *}$ \\ ${ }^{\prime}$ Department of Geological Sciences, University of Michigan, Ann Arbor, MI 48109-1063 (U.S.A.) \\ ${ }^{2}$ Department of Geology, Stanford University, Stanford, CA 94305-2115 (U.S.A.) \\ ${ }^{3}$ Scottish Universities Research and Reactor Centre, East Kilbride, Glasgow, G75 0QU (U.K.)
}

Received May 31, 1989; revised version received June 30, 1989

\begin{abstract}
The high-silica rhyolite lavas of Glass Mountain, California, provide a detailed record of the evolution of the Long Valley magmatic system during the $1.4 \mathrm{~m}$.y. prior to the catastrophic eruption of the voluminous zoned rhyolitic Bishop Tuff at $0.73 \mathrm{Ma}$. The older lavas of Glass Mountain are extremely cvolved, and were erupted from 2.1 to $1.2 \mathrm{Ma}$ with ${ }^{87} \mathrm{Sr} /{ }^{86} \mathrm{Sr}$ of $0.707-0.739$ and $\epsilon_{\mathrm{Nd}}$ of -3 to -4 , whereas the younger lavas are slightly less evolved and were erupted between 1.2 and $0.79 \mathrm{Ma}$ with ${ }^{87} \mathrm{Sr} /{ }^{86} \mathrm{Sr}$ of $0.706-0.707$ and $\epsilon_{\mathrm{Nd}}$ close to -1 , essentially identical to the $\mathrm{Sr}$ and $\mathrm{Nd}$ isotopic compositions of the Bishop Tuff. Neither the older nor younger lavas display a relationship between the isotopic compositions of $\mathrm{Sr}$ and $\mathrm{Nd}$. The $\mathrm{Pb}$ isotopic compositions are effectively uniform at ${ }^{206} \mathrm{~Pb} /{ }^{204} \mathrm{~Pb}=19.13-19.17$. A group of older lavas that outcrop in a northwest-trending band near the topographic rim of the caldera collectively define an apparent $\mathrm{Rb}-\mathrm{Sr}$ isochron age $(t)$ of $2.09 \pm 0.06 \mathrm{Ma}$ with an intercept of ${ }^{87} \mathrm{Sr} /{ }^{86} \mathrm{Sr}=0.7060 \pm 3$, whereas analyzed older lavas outcropping outboard of this band define an isochron of $1.90 \pm 0.02 \mathrm{Ma}\left(\left({ }^{87} \mathrm{Sr} /{ }^{86} \mathrm{Sr}\right)_{t}=0.7063 \pm 4\right)$. These isochron ages are identical to the $\mathrm{K}-\mathrm{Ar}$ ages for oldest erupted rhyolites in the two regions, respectively. The younger lavas away from the caldera define an apparent $\mathrm{Rb}-\mathrm{Sr}$ isochron age $(t)$ of $1.14 \pm 0.08$ Ma with the same $\left.{ }^{87} \mathrm{Sr} /{ }^{86} \mathrm{Sr}\right)_{t}$ as the older lavas. The agreement between the ${ }^{87} \mathrm{Sr} /{ }^{86} \mathrm{Sr}$ ratios of the rhyolite magmas when emplaced in the Long Valley magmatic system (0.706) and that of basaltic lavas in the region (0.7059-0.7062) suggests that the $\mathrm{Sr}$ isotopic compositions of these $\mathrm{Sr}$-poor rhyolites may be totally dominated by $\mathrm{Sr}$ from mantle-derived components.

$\mathrm{K}-\mathrm{Ar}$ ages and stratigraphic relations for both the older and younger lavas seem to rule out the possibility that the $\mathrm{Rb}-\mathrm{Sr}$ isochron ages record the times of eruption. The very low $\mathrm{Sr}$ concentrations of all the lavas (down to $0.1 \mathrm{ppm}$ ) cannot be produced simply by crustal fusion; the extremely high and variable $\mathrm{Rb} / \mathrm{Sr}$ ratios (up to 2000) and low $\mathrm{Sr}$ concentrations must be due to extensive fractional crystallization. We interpret the isochrons as dating this process. To produce the observed volume of highly evolved rhyolite requires differentiation of a sizeable body of magma; thus the older lavas may have been derived from an evolved roof zone of a differentiated magma chamber that was present in the Long Valley region as early as $2.1 \mathrm{Ma}$. The similarity of the isotopic compositions of the younger Glass Mountain lavas and the Bishop Tuff, as well as the isochronous relationship of most of the younger lavas, indicate that the chamber containing the magma later to erupt as the younger lavas of Glass Mountain and the Bishop Tuff was already formed, isotopically homogenized, and had developed an evolved roof zone by about $1.1 \mathrm{Ma}$. There is no evidence for significant assimilation of crustal rocks or input of mantle-derived magma into the upper reaches of the system after this time.

The preservation of isochronous relationships between lavas (and their constituent glasses) implies that most of the crystallization of the magma (i.e., that which affected $\mathrm{Rb} / \mathrm{Sr}$ ratios) took place in discrete dateable events. The fact that the three isochrons have the same $\left({ }^{87} \mathrm{Sr} /{ }^{86} \mathrm{Sr}\right){ }_{t}$ requires that the magmas did not exist for long as highly evolved liquids prior to the differentiation events that established the range of $\mathrm{Rb} / \mathrm{Sr}$ ratios and the isochrons, as such magmas would increase in ${ }^{87} \mathrm{Sr} /{ }^{86} \mathrm{Sr}$ by $0.0002-0.005$ per 100,000 years (depending on $\mathrm{Rb} / \mathrm{Sr}$ ratio) due to in-situ decay. Comparing the isochron ages of the Glass Mountain lavas with times of their eruption yields residence times of silicic magma as great as $0.7 \mathrm{~m} . \mathrm{y}$. To prevent the rhyolitic magma from cooling and crystallizing during these intervals, heat must have been supplied to the system, presumably in the form of new additions of magma. This magma must not have reached the upper regions of the magma reservoir; otherwise the isochrons would have been destroyed by mixing in these Sr-poor rocks.
\end{abstract}

Present addresses:

* Department of Earth and Space Sciences, University of California, Los Angeles, CA 90024, U.S.A.

** Charles Evans and Associates, 301 Chesapeake Drive, Redwood City, CA 94063, U.S.A. 


\begin{abstract}
Our interpretation of the isotopic data for Glass Mountain is at variance with recent models that invoke repeated melting of the deep crust rather than episodic tapping of magma chambers as mechanisms for producing repeated rhyolitic eruptions spanning periods of $10^{5}-10^{6}$ years. The evidence for Long Valley is rather that major differentiation accompanies fresh inputs of magma into the system and that magma is maintained in stable zones in the chamber for hundreds of thousands of years.
\end{abstract}

\section{Introduction}

The Long Valley caldera in eastern California is well known as the source of the Bishop Tuff, a voluminous, compositionally zoned rhyolitic ignimbrite that erupted at $0.73 \mathrm{Ma}$ [1]. It has been the site of young (600-year-old) volcanism and is one of the few areas of the U.S. where it is possible that a silicic magma reservoir is present [2]. The Bishop Tuff has received a great deal of attention recently because it has been a focus for discussion concerning the differentiation mechanisms that produce extreme trace-element gradients in voluminous rhyolitic eruptions [3-5]. It is important to obtain time-resolved information on the entire eruptive history of the Long Valley magmatic system if differentiation processes are to be properly understood.

Notwithstanding the interest from this standpoint, there are yet greater reasons for studying the evolution of the Long Valley magmatic system. It has become apparent that large-volume granites and rhyolites in convergent-margin settings, as well as alkaline anorogenic granites, have a significant component of $\mathrm{Nd}$ that is considerably more radiogenic than that found in the local upper crust [6-14]. A reasonable explanation for these data is that many granites and rhyolites are not simply the products of crustal fusion, but contain mantle-derived components, even in cases in which there are few associated basaltic rocks. The problem is to explain the acquisition of mantle-like isotopic characteristics by a high-silica rhyolite system. Models that invoke differentiation of mantle-derived basalt are faced with impossibly large volumes of crustal cumulates in order to mass balance up to $3000 \mathrm{~km}^{3}$ of rhyolite observed in single eruptions $[15,16]$, and models that involve progressive contamination of basalt by crustal components during fractional crystallization cannot account for the common bimodal association of basalt and rhyolite.

There is a third important reason for studying the Long Valley magmatic system. There is con- siderable debate regarding the origin of rhyolites erupted episodically over periods of $10^{5}-10^{6}$. years. For example, Smith [15], Hildreth [16], Bacon et al. [17], and Mahood [18] have presented models in which high-level, large-volume magma chambers are the immediate sources of many rhyolites that erupt over long periods. In contrast, Huppert and Sparks [19] have recently questioned the longevity of high-level rhyolitic magma chambers and have proposed that episodic silicic volcanism may be produced by repeated melting of the deep crust, without the necessity for a more "permanent" magma chamber.

One obvious approach in the determination of how rhyolites are produced is to study magmatic systems that have been active over a considerable period and for which high-quality chronological information is available, such that one can virtually observe how rhyolites evolve as a function of time. Following earlier such isotopic studies of Coso [20], La Primavera [13], and Yellowstone $[11,21]$, we here report a combined $\mathrm{Nd}, \mathrm{Sr}$ and $\mathrm{Pb}$ isotopic study of the rhyolite lavas erupted during the $1.4 \mathrm{~m}$.y. prior to the explosive eruption of the Bishop Tuff.

\section{Geologic background}

The geology and geochronology of the rocks of the Long Valley region have been described in detail in a variety of publications (e.g., [1 3,22 24]), to which the reader is referred for full information. The country rocks surrounding the Long Valley caldera are Jurassic and Cretaceous granitoids of the Sierra Nevada batholith that intrude Paleozoic and Mesozoic metavolcanic and metasedimentary rocks of the Mount Morrison and Ritter Range roof pendants $[25,26]$. The earliest stages of the Long Valley magmatic system are represented by $2.6-3.2 \mathrm{Ma}$ basalts, andesites, and rhyodacites [1]. These were followed by the high-silica rhyolites of Glass Mountain, a complex of lava domes and flows with intercalated 


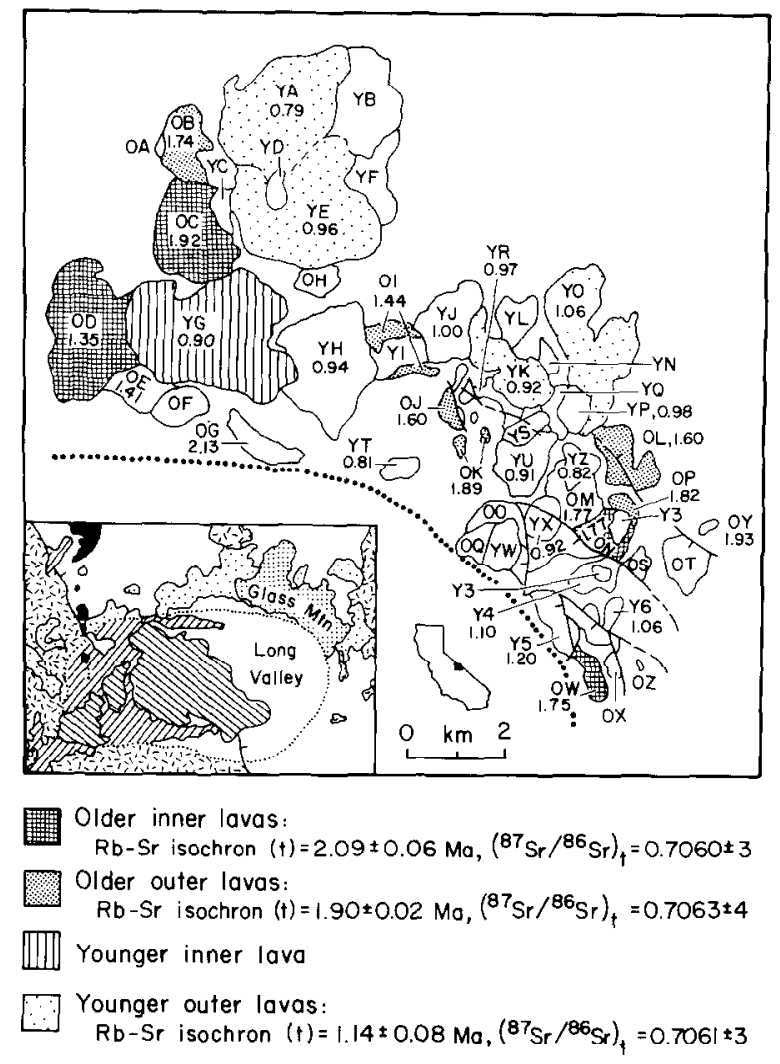

Fig. 1. Geologic map (modified from Metz and Bailey [24] and Metz and Mahood [27]) showing distribution of Glass Mountain lavas with unit names and their eruption ages (where determined). Patterned units are those analyzed during this isotopic study. Letters label flow units, with older lavas beginning with $\mathrm{O}$ and younger lavas with $\mathrm{Y}$. Dotted line $=$ margin of Long Valley caldera. Unmarked areas on map and inset are tuffs of Glass Mountain, Bishop 'Tuff, caldera lake sediments, or surficial deposits. Inset shows location of Glass Mountain on the northeastern margin of Long Valley caldera. Random dash pattern $=$ granitic and metamorphic wall rocks; stipple = precaldera Long Valley lavas; diagonal ruling = Pleistocene postcaldera lavas that are rhyolitic and rhyodacitic (NW-striking pattern) or trachybasaltic (SW-striking pattern); solid = largely Holocene Inyo and Mono Craters.

pyroclastic material, which was truncated by caldera collapse following eruption of the Bishop Tuff (Fig. 1).

The precaldera rhyolites of Glass Mountain were the subject of a detailed geochronologic, petrologic, and geologic study by Metz, Mahood and Bailey [22,24,27,28]. All lavas and tephra are metaluminous high-silica rhyolites containing 76.8-77.9 wt.\% $\mathrm{SiO}_{2}$ (volatile-free). The oldest preserved lava is $2.1 \mathrm{Ma}$ and the youngest is 0.79 , but the scarcity of units with ages in the range 1.3-1.1 Ma has led to the division of the lavas into an older and younger group [22]. There was an apparent gap of about 60,000 years between eruption of the youngest exposed Glass Mountain lava and the Bishop Tuff. The older lavas (2.1-1.2 Ma) have a wider range of incompatible element concentrations, showing a more restricted range as a function of time. The younger lavas $(1.2-0.79 \mathrm{Ma})$ are relatively uniform in composition. Overall, the lavas become chemically less evolved with time. Metz and Mahood [22,27] interpreted the wide range of chemical compositions in the older lavas, the larger range in phenocryst modes, the eruption of magmas with different compositions at nearly the same time in different parts of the field, and the smaller volume of individual lavas as suggesting either that more than one magma body was tapped during eruption of the older lavas or that a single chamber tapped by all lavas was small enough that the composition of its upper reaches was easily affected by new additions of crustal partial melts. They interpreted the relative chemical, mineralogical, and isotopic homogeneity of the younger Glass Mountain lavas as reflecting eruptions from a large integrated upper crustal magma chamber that finally coalesced during a period of few eruptions between 1.4 and $1.2 \mathrm{Ma}$.

The Bishop Tuff is strikingly zoned in composition and mineralogy [3]. The earliest-erupted, most differentiated material is thought to have come from near the top of the magma chamber and is similar chemically and isotopically (though not identical) to the last-erupted Glass Mountain lavas. The last-erupted Bishop Tuff, thought to come from deeper in the magma chamber, is more mafic, richer in crystals, and has higher equilibration temperatures than the earlier erupted material [3]. Halliday et al. [12] demonstrated that the Bishop Tuff was essentially uniform in terms of $\mathrm{Nd}$ isotopic composition despite the large range in concentrations of most trace elements. If the Glass Mountain eruptive units merely represent tapping of the uppermost more-evolved parts of the Bishop Tuff magma chamber, there should not be any difference in $\mathrm{Nd}$ isotopic composition. If, as suggested by Metz and Mahood [27], the chemically variable earliest eruptions from Glass Mountain are derived from isolated pockets of magma prior to coalescence of the magma cham- 
ber that was tapped by the Bishop Tuff eruption at $0.73 \mathrm{Ma}$, it is only the later Glass Mountain lavas that might be expected to be isotopically similar to the Bishop Tuff.

\section{Techniques}

All isotopic analyses were performed at the Scottish Universities Research and Reactor Centre (S.U.R.R.C.) at East Kilbride and at the University of Michigan. $\mathrm{Nd}, \mathrm{Sr}$ and $\mathrm{Pb}$ isotopic techniques at S.U.R.R.C. followed the methods outlined previously [12] with the difference that the blanks were around $0.1 \mathrm{ng}$ for $\mathrm{Nd},<1 \mathrm{ng}$ for $\mathrm{Sr}$ and $<1 \mathrm{ng}$ for $\mathrm{Pb}$, and that the $\mathrm{Nd}$ separation technique utilized the PTFE-HDEHP method [29]. $\mathrm{Rb}$ and $\mathrm{Sr}$ concentrations were determined by isotope dilution using ${ }^{87} \mathrm{Rb}(>99 \%)$ and ${ }^{84} \mathrm{Sr}(>$ 99\%) tracers and are accurate to better than $1 \%$. ${ }^{87} \mathrm{Sr} /{ }^{86} \mathrm{Sr}$ ratios were determined on totally spiked aliquots. Procedures at the University of Michigan were similar to this except that all column volumes were smaller $(3 \mathrm{ml})$ and all sample-exposed chemical operations were performed in local clean air boxes with an over-pressure of better than class10 -quality clean air. Total Sr blanks were $<100$ pg at the University of Michigan.

All mass spectrometric analyses at S.U.R.R.C. were performed on the V.G. Isomass 54E singlecollector mass spectrometer, except for the $\mathrm{Rb}$ analyses, which were performed on the single-collector V.G. Micromass MM30B mass spectrometer. All the measurements were made using a single Faraday detector with a $10^{11}-\mathrm{ohm}$ resistor in the amplifier. The average ${ }^{87} \mathrm{Sr} /{ }^{86} \mathrm{Sr}$ ratio for the NBS987 standard was $0.71027 \pm 2(2 \sigma$ mean $)$, and the average ${ }^{143} \mathrm{Nd} /{ }^{144} \mathrm{Nd}$ ratio for the $\mathrm{La}$ Jolla $\mathrm{Nd}$ standard was $0.51185 \pm 2$ on the Isomass 54E. All the isotopic analyses at the University of Michigan were performed on two V.G. Sector multicollector thermal ionisation mass spectrometers. $\mathrm{Rb}$ was analysed on triple Ta filaments using "static" simultaneous multicollection. $\mathrm{Sr}$ was loaded with $\mathrm{Ta}_{2} \mathrm{O}_{5}$ powder on zone-refined $\mathrm{Re}$ filaments and was measured using multidynamic analysis with a standard array of six Faraday collectors with the axial detector set back from the plane of the other detectors. Using these procedures we obtained ${ }^{87} \mathrm{Sr} /{ }^{86} \mathrm{Sr}$ of $0.710242 \pm 8(2 \sigma$ mean, $N=13$ ) for NBS987 on this machine at the time these analyses were performed. The flight tube pressure was maintained at $<2 \times 10^{-9} \mathrm{mbar}$ during the course of these analyses. Nd was measured as the metal ion using triple-filament assemblies and multidynamic analysis on a Sector with a Multi-Two detector block (i.e., seven independently adjustable Faraday collectors in the same plane). Using these procedures on this machine, we obtained ${ }^{143} \mathrm{Nd} /{ }^{144} \mathrm{Nd}$ of $0.511855 \pm 8(N=$ 18) for the La Jolla Nd standard. All ${ }^{87} \mathrm{Sr} /{ }^{86} \mathrm{Sr}$ ratios are presented normalized to ${ }^{84} \mathrm{Sr} /{ }^{86} \mathrm{Sr}=$ 0.1194 , and all ${ }^{143} \mathrm{Nd} /{ }^{144} \mathrm{Nd}$ ratios are presented normalized to ${ }^{146} \mathrm{Nd} /{ }^{144} \mathrm{Nd}=0.7219$. Power-law fractionation corrections were used for all $\mathrm{Nd}$ and $\mathrm{Sr}$ isotopic data. All $\mathrm{Pb}$ isotopic ratios are presented after normalization to NBS981 for which a fractionation factor of $0.1 \%$ per a.m.u. was measured.

All whole-rock and glass samples analyzed were extremely fresh, dense, and nonhydrated obsidian. Glass and sanidine were separated from other phases using diluted bromoform.

\section{Results}

$\mathrm{Nd}, \mathrm{Sr}$ and $\mathrm{Pb}$ isotopic data together with $\mathrm{Rb}$, $\mathrm{Sr}, \mathrm{Sm}$ and $\mathrm{Nd}$ concentrations are presented for 15 whole-rock powders, 5 sanidine separates and 2 glass separates from Glass Mountain lavas in Table 1 . The calculated ${ }^{87} \mathrm{Sr} /{ }^{86} \mathrm{Sr}$ initial ratio is a sensitive function of the age and $\mathrm{Rb} / \mathrm{Sr}$ ratio for many of the samples; hence errors in the K-Ar dating can result in errors in the calculated initial ratio and an apparently greater isotopic variability. The errors calculated for the initial ratios in Table 1 combine quadratically the run precision on ${ }^{87} \mathrm{Sr} /{ }^{86} \mathrm{Sr}$ with the estimated uncertainty in $\mathrm{Rb} / \mathrm{Sr}$. No account of possible errors in the age is included in Table 1, but they are illustrated in Fig. 2 , in which the $\mathrm{Sr}$ concentrations and $\mathrm{Nd}, \mathrm{Pb}$ and $\mathrm{Sr}$ isotopic compositions at the time of their eruption for samples from this study plus those of the Bishop Tuff [12] are plotted in order of age.

The concentration of $\mathrm{Sr}$ in the Glass Mountain rhyolites and Bishop Tuff ranges through three orders of magnitude (Table 1, Fig. 2). Some of the older Glass Mountain samples have $\mathrm{Rb} / \mathrm{Sr}$ greater than 2,000, which are among the highest recorded for rhyolites (although they are approached by values at Yellowstone and La Primavera [11,13]). 


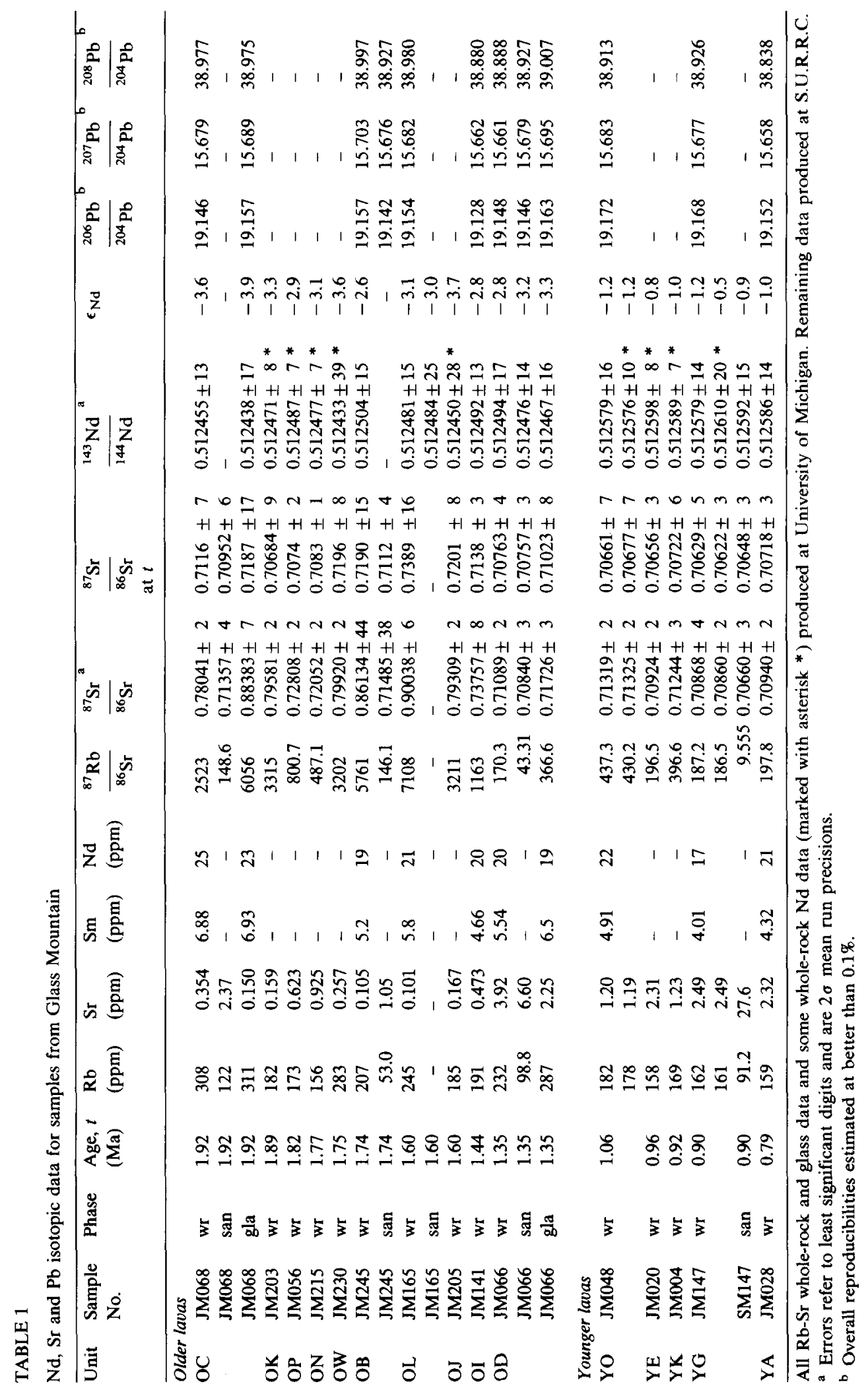




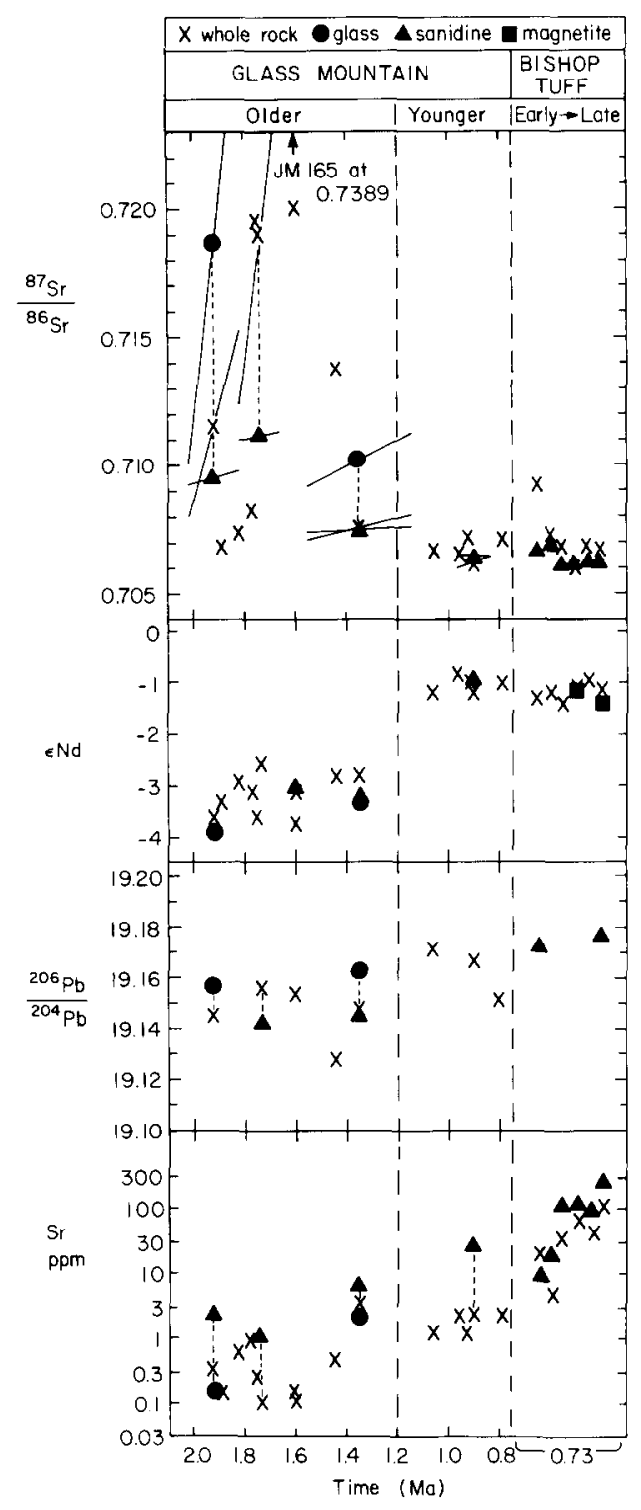

Fig. 2. Neodymium, lead and strontium isotopic compositions on eruption and $\mathrm{Sr}$ concentrations of Glass Mountain lavas (this study) and the Bishop Tuff [12] in eruptive order. Effect of maximum uncertainty in age on the calculated $\mathrm{Sr}$ isotopic compositions at the time of eruption shown for samples with mineral separates. Lead isotopic data for the Bishop Tuff are unpublishëd data of M. Delevaux and B.R. Doe.

The older lavas of Glass Mountain have $\mathrm{Sr}$ concentrations as low as $0.1 \mathrm{ppm}$ and highly variable initial ${ }^{87} \mathrm{Sr} /{ }^{86} \mathrm{Sr}$ ratios, which range from 0.707 to 0.739 . The younger lavas have higher $\mathrm{Sr}$ concentrations (1.2-2.5 ppm) and have lower and more uniform initial ${ }^{87} \mathrm{Sr} /{ }^{86} \mathrm{Sr}$ of $0.706-0.707$, which are essentially the same as those of the non-hydrated Bishop Tuff [12,30]. However, all of the $\mathrm{Sr}$ isotopic compositions calculated for the time of eruption display considerable variation.

A similar but slightly simpler picture emerges from the $\mathrm{Nd}$ isotopic data (Fig. 2). These demonstrate unequivocally that there is a marked change in the magmatic system at about $1.2 \mathrm{Ma}$. The older lavas have relatively negative and slightly variable $\epsilon_{\mathrm{Nd}}$ of around -3 , and the younger lavas have uniform $\epsilon_{\mathrm{Nd}}$ of close to -1 , identical within analytical error to the value for the Bishop Tuff [12]. The change at $1.2 \mathrm{Ma}$ would be compatible with incorporation of a greater proportion of new mantle-derived (as opposed to old crust-derived) components at this time. None of the samples exhibit measurable $\mathrm{Nd}$ isotopic disequilibrium between whole rock, glass, and phenocryst phases, regardless of age.

The $\mathrm{Pb}$ isotopic data display only a hint of a similar distinction between older and younger lavas. Two out of the three post-1.2 Ma lavas have slightly higher ${ }^{206} \mathrm{~Pb} /{ }^{204} \mathrm{~Pb}$ than is found in the earlier lavas. These differences are barely significant given the analytical reproducibility of about $0.1 \%$ achieved during the course of this experiment. We do not consider that we have convincingly demonstrated any significant $\mathrm{Pb}$ isotopic disequilibrium between phases in a single sample. These data are very similar to lead isotopic data for sanidines from the Bishop Tuff (M. Delevaux and B.R. Doe, unpublished data) and to high-silica rhyolites of the nearby Coso Range [20].

The present-day $\mathrm{Rb}$-Sr isotopic data for all the whole-rock and glass samples are plotted on conventional isochron diagrams in Fig. 3. The data for the older lavas lie on two extremely well-defined linear arrays (six data points each) with essentially identical ${ }^{87} \mathrm{Sr} /{ }^{86} \mathrm{Sr}$ intercepts of 0.7060 \pm 3 and $0.7063 \pm 4$ (Fig. 3b). Each isochron is defined by samples with widely different eruptive ages (indicated in brackets next to each point in Fig. 3), but there is no correlation between eruptive age and $\mathrm{Rb} / \mathrm{Sr}$ or ${ }^{87} \mathrm{Sr} /{ }^{86} \mathrm{Sr}$ on eruption. The samples defining the line of steeper slope (i.e., greater age) outcrop in a northwest-trending band near the topographic rim of the caldera (Fig. 1), whereas those defining the isochron of shallower slope occur outboard of this band. The apparent ages corresponding to these arrays are $2.09 \pm 0.06$ 

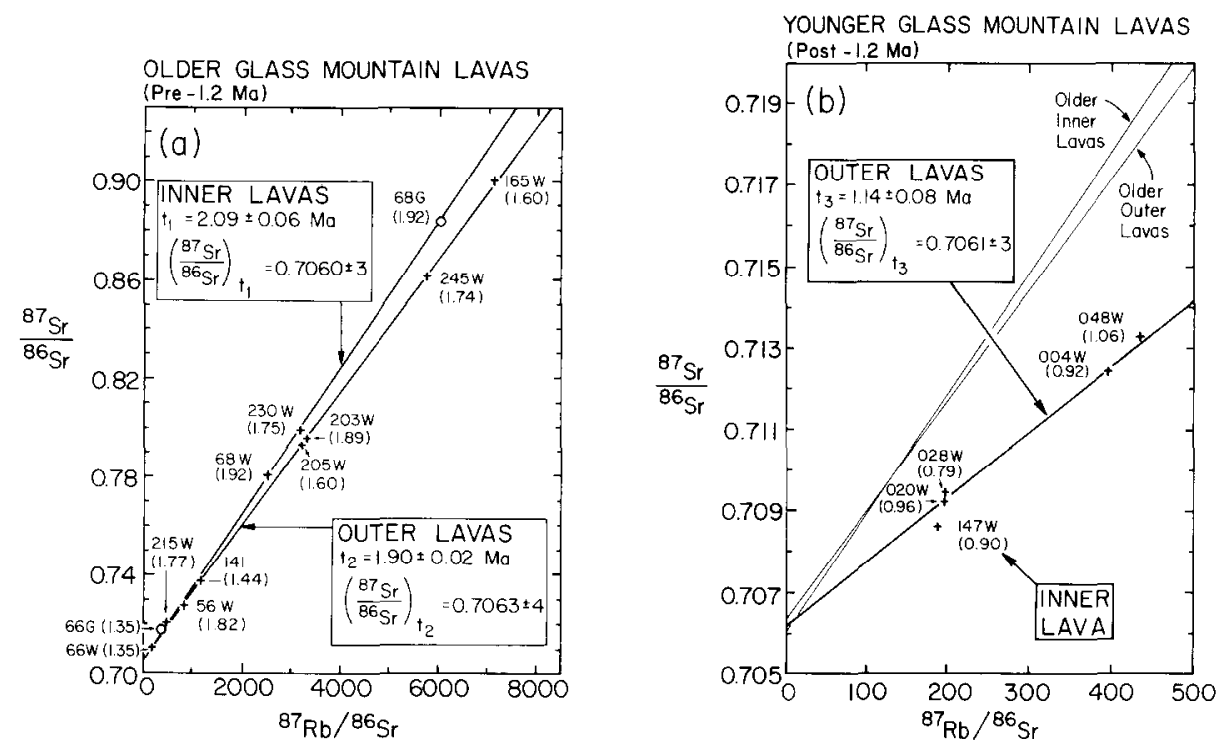

Fig. 3. $\mathrm{Rb}-\mathrm{Sr}$ isotopic evolution diagram for present-day $\mathrm{Sr}$ isotopic data for the (a) older and (b) younger lavas of Glass Mountain.

$\mathrm{Ma}$ and $1.90 \pm 0.02 \mathrm{Ma}$ (2o errors), respectively. These ages coincide with the oldest K-Ar ages that have been obtained in the respective areas, namely $2.13 \pm 0.06 \mathrm{Ma}$ and $1.93 \pm 0.06 \mathrm{Ma}(2 \sigma$ errors $)$ [22].

The $\mathrm{Rb}-\mathrm{Sr}$ isotopic data for the younger lavas are shown in Fig. 3b. As with the older lavas, they are divided according to geography, with one sample from close to the caldera rim and the remaining four from farther away (Fig. 1). These latter four define an apparent isochron age $(t)$ of $1.14 \pm$ $0.08 \mathrm{Ma}$, identical to the K-Ar ages of the oldest younger lavas of Glass Mountain [22]; the intercept $\left({ }^{87} \mathrm{Sr} /{ }^{86} \mathrm{Sr}\right)_{t}$ of $0.7061 \pm 3$ is indistinguishable from the intercept for the older lavas. The sample from a flow close to the caldera rim plots below the isochron defined by the other data points.

\section{Interpretation of apparent inherited $\mathrm{Rb}-\mathrm{Sr}$ iso- chrons}

The conventional interpretation of $\mathrm{Rb}-\mathrm{Sr}$ isochrons from a cogenetic suite of igneous rocks is that the age corresponds to the time when the magma differentiated and produced a range in $\mathrm{Rb} / \mathrm{Sr}$. If the $\mathrm{Rb}-\mathrm{Sr}$ isochron ages are much older than the eruptive ages, the data would usually be interpreted as reflecting contamination (i.e., open-system behavior) or incomplete homogeni- zation of magma during melting of a source. In the case of Glass Mountain, a number of highly evolved magmas were erupted at different times, yet collectively define $\mathrm{Rb}-\mathrm{Sr}$ isochrons corresponding to ages that are coincident with the earliest eruptions in that area. We think that the most reasonable explanation for this is that these isochrons date the major differentiation of batches of magma, that these crystallization events only slightly preceded (or even were concurrent with) the earliest tapping of the magma batches, and that the differentiated magmas were maintained thermally so that they could be tapped as much 0.7 m.y. later.

If this interpretation is correct, there are important implications for the longevity of magma batches and the nature of convection in large silicic systems. Therefore it is necessary to demonstrate that the data cannot be explained in any other way.

(1) The simplest explanation - that the $\mathrm{Rb}-\mathrm{Sr}$ isochrons date the times of eruption of groups of lavas - is at variance with a large body of internally consistent, high-quality data. In the fourteen cases in which Metz and Mahood [22,28] dated two or more lavas with mapped stratigraphic relations [24,28], the K-Ar dates are in accord with the relative ages. Three sets of duplicate analyses of glass samples replicated well, as did two dates on 


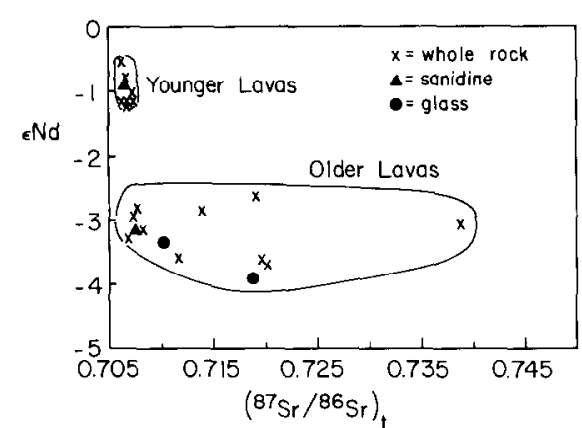

Fig. 4. Plot of $\epsilon_{\mathrm{Nd}}$ versus ${ }^{87} \mathrm{Sr} /{ }^{86} \mathrm{Sr}$ at the time of eruption for older and younger lavas of Glass Mountain.

samples from different parts of a single lava flow. Sanidine and whole rock from one of the older lavas yielded the same age within analytical uncertainty. None of the samples yielded ages younger than the $0.73 \mathrm{Ma}$ date for the Bishop Tuff. If argon loss had occurred, there is no reason why the systematic relationship between $\epsilon_{\mathrm{Nd}}$ and $\mathrm{K}-\mathrm{Ar}$ age (Fig. 2) should be preserved. For these reasons we think that there were no significant problems with either extraneous argon or argon loss. Therefore the K-Ar ages appear to be accurate estimates of the time of eruption.

(2) Although both erupted $\mathrm{Sr}$ and $\mathrm{Nd}$ isotopic compositions are variable, there is clearly no correlation between the two in the older lavas (Fig. 4), which might otherwise have provided evidence that the variation in erupted ${ }^{87} \mathrm{Sr} /{ }^{86} \mathrm{Sr}$ ratio reflected solely the effects of crustal contamination. Similarly, the fits of the isochrons are good compared with the weak correlations between the ${ }^{87} \mathrm{Sr} /{ }^{86} \mathrm{Sr}$ ratio on eruption and $1 / \mathrm{Sr}$ or ${ }^{87} \mathrm{Rb} /{ }^{86} \mathrm{Sr}$, suggesting that the isochrons are not a product of assimilation or mixing with crustal melts.

(3) All three isochrons define the same $\left({ }^{87} \mathrm{Sr} /{ }^{86} \mathrm{Sr}\right)_{\mathrm{t}}$ intercept of 0.706 , whereas the erupted ratios of the older lavas are highly variable and non-systematic (0.706-0.739). Furthermore, the intercept values for both the older and younger lavas are identical to the ${ }^{87} \mathrm{Sr} /{ }^{86} \mathrm{Sr}$ ratios of the relatively unfractionated basalts in the region (0.7059-0.7062) ([31]; D. Ormerod, personal communication, 1988).

(4) The apparent isochrons cannot be the product of aggregation of partial melts that did not undergo isotopic homogenization. It is effectively impossible to generate the low Sr concentrations of Glass Mountain lavas by partial melting of any rock with more than a few ppm $\mathrm{Sr}$ because this process can never deplete a compatible element by more than the inverse of the bulk distribution coefficient, no matter how small the degree of partial melting. This is only made worse by the high viscosity of rhyolitic liquids, which make it unlikely that melt fractions of less than $10 \%$ will escape the partial melting zone (e.g., [32]). Given the fact that potential source rocks with such low Sr concentrations would occur in small volumes and that most Sierran country rocks contain 500-1000 ppm Sr [6,33], we conclude that Glass Mountain magmas were instead the product of extreme differentiation in the crust. Furthermore, these magmas were clearly not contaminated with typical Sierran country rocks after differentiation to low Sr concentrations. Extensive fractionation of an assemblage rich in plagioclase and sanidine can produce low concentrations provided the partition coefficients are high. This receives some support from the very high apparent $\mathrm{Sr}$ partition coefficient (18) for sanidine from sample JM068 (Table 1) and from large values reported by Leeman and Phelps [34]. The extremely low Sr concentrations require that all Glass Mountain magmas were derived from magma bodies large enough to undergo extensive fractional crystallization. As such, it is possible that even the magmas erupted as the older lavas represent differentiates of a single voluminous magma chamber.

(5) The agreement between the $\mathrm{Rb}-\mathrm{Sr}$ isochron ages and the oldest $\mathrm{K}$-Ar ages for the eruptive units in that area would not be predicted by a contamination model, but is what would be expected if crystallization and/or volcanism accompany a fresh input of magma into the upper reaches of the crust.

\section{The systematics of generating, preserving, and disturbing $\mathbf{R b}-\mathrm{Sr}$ isochrons}

The $\mathrm{Rb}-\mathrm{Sr}$ systematics of magma differentiation and mixing are simple; the range of possibilities for both the generation and preservation of $\mathrm{Rb}-\mathrm{Sr}$ isochrons is illustrated in Fig. 5 and discussed below.

We emphasize at the outset the important distinction between the case in which phenocrysts change their $\mathrm{Sr}$ isotopic compositions purely as a 

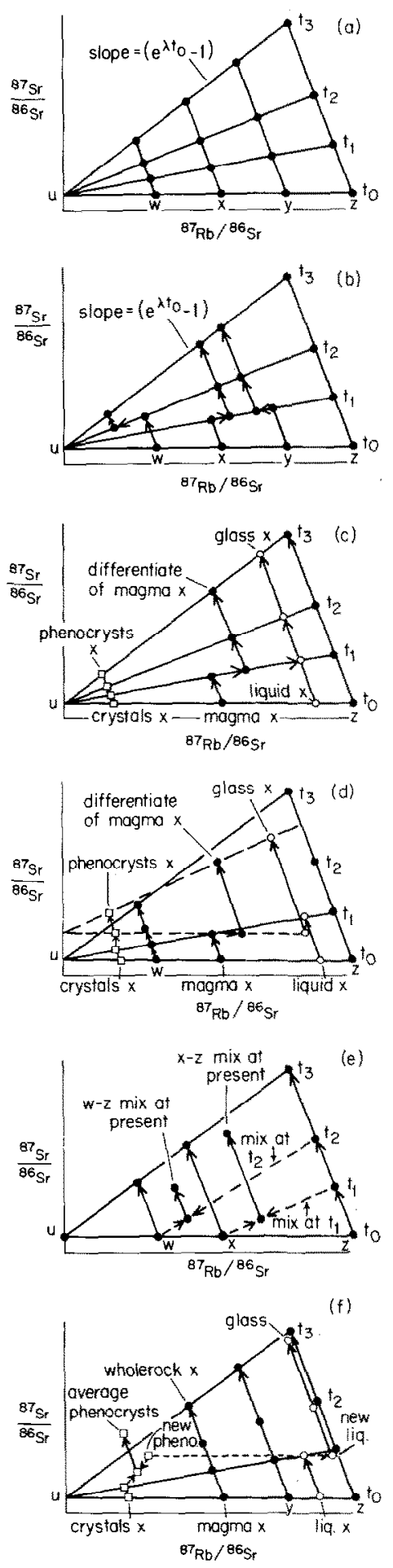

result of in-situ radioactive decay of $\mathrm{Rb}$ whilst resident in the magma and the case in which the crystals re-equilibrate with the magma. At present there are insufficient experimental data for $\mathrm{Sr}$ diffusion in feldspar to judge how realistic it is to claim that feldspars can preserve their isotopic compositions in silicic magmas over periods of hundreds of thousands of years. Experimental work by Misra and Venkatasubramanian [36] suggests that feldspar phenocrysts should equilibrate with their host liquids in periods of about 1000 years, in which case apparent disequilibrium must be attributed to contamination of the matrix after eruption (e.g. due to Sr addition on secular hydration of glass, as found for the Bishop Tuff [12]) or to contamination of the matrix shortly before eruption (e.g., [37]) or by incorporation of xenocrysts during the eruption process itself. We note, however, that evidence for $\mathrm{Sr}$ and $\mathrm{Pb}$ isotopic disequilibrium between feldspars and their host magmas is not uncommon and has been reported from both volcanic and plutonic rocks (e.g., [35,37-42]), suggesting that diffusion of Sr in feldspar is slower than predicted by existing experimental work. Further discussion of this matter is fruitless without better knowledge of the diffusion coefficients for $\mathrm{Sr}$ in feldspar and a more comprehensive data set for the Glass Mountain phenocrysts, which is the subject of ongoing research.

If an isotopically uniform magma ( $u$ in Fig. 5a)

Fig. 5. Diagrams illustrating $\mathrm{Rb}-\mathrm{Sr}$ isotopic systematics of crystallization and mixing as they pertain to the formation and preservation of isochrons. (a) Evolution of whole-rock isochrons defined by differentiated magmas $(w, x, y, z)$ fractionated from parent magma $(u)$ at $t_{0}$. (b) Preservation of isochronous relationship upon mixing between differentiates ( $x$ and $y$ ) and backmixing of differentiate $(w)$ with parental magma $(u)$. (c) Preservation of isochronous relationship upon crystallization or crystal removal if crystals do not re-equilibrate isotopically with the host liquid. (d) Re-equilibration of crystals and glass results in their displacement off the wholerock isochron. Crystal removal displaces whole rock from isochron. (e) Backmixing of liquids that have evolved by in-situ decay $\left(z\right.$ at $t_{1}$ and $t_{2}$ ) with newly differentiated magma batches ( $w$ and $x$ ) results in dispersion below the isochron. (f) Crystallization of a second generation of phenocrysts results in significant displacement of bulk phenocrysts above the isochron, but only slight displacement of glass, the effect depending on the amount of crystals formed and the bulk distribution coefficients for $\mathrm{Sr}$ and $\mathrm{Rb}$. 
differentiates to produce liquids with a range of $\mathrm{Rb} / \mathrm{Sr}$ ratios $(w, x, y$, and $z)$ at a time $t_{0}$, and no further differentiation, mixing, or contamination follow this event, the present-day $\mathrm{Rb}-\mathrm{Sr}$ isotopic data for these liquids (or their chilled equivalents) will define a slope corresponding to the age of differentiation (Fig. 5a). If some of these same batches of magma partially mix with each other (e.g., $x$ and $y$ at $t_{1}$ in Fig. 5b), the mixing line will be colinear with the isochron at that time and so the present-day $\mathrm{Rb}-\mathrm{Sr}$ isotopic data will still define the age of differentiation $\left(t_{0}\right)$. Similarly, if some of the batches of differentiated magma (e.g., $w$ in Fig. 5b) partially back-mix with the parental magma $(u)$ at any time $\left(t_{2}\right.$ in Fig. $\left.5 \mathrm{~b}\right)$, the slope of the $\mathrm{Rb}-\mathrm{Sr}$ isochron will still define the age of differentiation $\left(t_{0}\right)$. In the case of the Glass Mountain rhyolites, however, the variation in $\mathrm{Rb} / \mathrm{Sr}$ ratio is controlled by the variation in the extremely low concentrations of Sr. Mixing with any magma having a low $\mathrm{Rb} / \mathrm{Sr}$ ratio has to be minimal unless the concentration of $\mathrm{Sr}$ is very low. If there were extensive mixing with a Sr-rich magma with low $\mathrm{Rb} / \mathrm{Sr}$ ratio (e.g., a less differentiated parent for the Glass Mountain lavas), an isochron would not be resolvable because all the points would plot near the intercept.

If each of the differentiates formed at $t_{0}$ is a mixture of liquid and crystals, subsequent removal of crystals will result in a change in the $\mathrm{Rb} / \mathrm{Sr}$ ratio of the differentiate, and the isochron may or may not be preserved depending on whether the phenocrysts are in isotopic equilibrium. If the individual crystals have behaved as closed systems and have not re-equilibrated isotopically with their host liquids, then crystal removal (say at time $t_{1}$ in Fig. 5c) will change the $\mathrm{Sr}$ isotopic composition of the differentiate in proportion to the $\mathrm{Rb} / \mathrm{Sr}$ ratio, i.c., along the isochron. The present-day $\mathrm{Rb}-\mathrm{Sr}$ isotopic data for the minerals, glass, and wholerock will be colinear and define the age of original crystallization and differentiation, $t_{0}$ (Fig. 5c). If the crystals in the differentiate (magma $x$ in Fig. $5 d)$ re-equilibrate with the host liquid (at $t_{1}$ say), then the present-day glass and phenocryst data will not lie on the isochron defined by the wholerock data; the glass will plot below and the feldspar phenocrysts will plot above the isochron. If isotopic equilibration were to take place in a discrete event (e.g., if there were a "closure tempera- ture" below which diffusional exchange effectively ceased), the data for the phenocrysts, whole rock and glass for the individual sample will define a line, the slope of which corresponds to the time of last equilibration $\left(t_{1}\right)$. If further differentiation of magma $x$ occurs, the resultant whole-rock data point will be displaced below the whole-rock isochron that otherwise would have been produced (Fig. 5d).

An isochron array cannot be generated by repeated differentiation of the original reservoir, nor by mixing between such later differentiates and an original differentiate (Fig. 5e).

Crystallization and separation of phases that do not contain significant $\mathrm{Rb}$ or $\mathrm{Sr}$ (e.g., quartz and magnetic) or have $\mathrm{Rb} / \mathrm{Sr}$ similar to the magma will obviously have no effect on the $\mathrm{Sr}$ isotopic and $\mathrm{Rb} / \mathrm{Sr}$ concentration ratios, nor on the slope of the isochron. The effect of crystallization, crystal separation, or re-equilibration of $\mathrm{Sr}$-rich phases like feldspar on the $\mathrm{Rb}-\mathrm{Sr}$ system for the whole rock and glass depends on the volume of crystals formed and the bulk distribution coefficients for $\mathrm{Sr}$ and $\mathrm{Rb}$. The change in $\mathrm{Rb} / \mathrm{Sr}$ ratio in a liquid as a result of crystallization can be expressed as:

$$
(\mathrm{Rb} / \mathrm{Sr})_{n} /(\mathrm{Rb} / \mathrm{Sr})_{o}=\left(M+D_{\mathrm{Sr}}\right) /\left(M+D_{\mathrm{Rb}}\right),
$$

where $(\mathrm{Rb} / \mathrm{Sr})=$ weight ratio, $\mathrm{n}=$ new liquid, $\mathrm{o}=$ original liquid, $M=$ mass ratio of new liquid to new crystals, and $D=$ bulk distribution coefficients for the new crystals.

For large values of $M$ (i.e., small proportions of crystals), the $\mathrm{Rb} / \mathrm{Sr}$ ratio of the liquid will be largely unaffected. This is important because many of the rhyolites at Glass Mountain are very crystal-poor (mostly less than 3\% [27]). In this instance, even if the phenocrysts lie off the wholerock isochron because part of the phenocrysts crystallized late or bccause carly-formed phenocrysts partially re-equilibrated isotopically with the host liquid, the trajectory of the glass phase on an isochron diagram may not be affected greatly. The case of late crystallization of a portion of the Sr-bearing phases on isochron systematics is illustrated in Fig. 5f. In Glass Mountain magmas this might model the effect of crystallization of sanidine, which is less abundant than plagioclase and, on the basis of the paragenetic sequence, appears to have crystallized late [27]. For example, if sanidine crystallizes after an initial differentia- 
tion event, the $\mathrm{Rb} / \mathrm{Sr}$ ratio of the liquid will be displaced to higher values, and the newly formed crystals will have the $\mathrm{Sr}$ isotopic composition of the liquid at that time (Fig. 5f). The isotopic composition of the bulk feldspar crystals at the present day will be a function of the weighted average of the $\mathrm{Rb}$ and $\mathrm{Sr}$ concentrations and ${ }^{87} \mathrm{Sr} /{ }^{86} \mathrm{Sr}$ ratios of crystals formed at $t_{0}$ and $t_{1}$ (unless the crystals re-equilibrate with the liquid). As long as the proportion of crystals is small, the $\mathrm{Rb} / \mathrm{Sr}$ of the liquid will change only slightly, thereby causing it to follow a trajectory on the $\mathrm{Rb}-\mathrm{Sr}$ isochron diagram such that the glass will plot very close to (but below) the isochron defined by whole-rock samples (Fig. 5f). The bulk crystals, however, will plot noticeably above the isochron. This is, in fact, what is observed for the Glass Mountain samples. The two glass points essentially lie along the isochron defined by the wholerock data for the inner band of older lavas, but three of four sanidine samples analyzed plot slightly above their respective isochrons. Either the sanidine crystallized late and is volumetrically minor, or it crystallized early and has partially re-equilibrated with the host melt.

The preservation of the isochrons defined by whole-rock samples at Glass Mountain despite the fact that sanidine plots above the isochrons echoes one of the points of the illustrative examples in Fig. 5-that isochronous relationships between magmas produced in a single differentiation event are fairly robust and will survive small amounts of crystallization, crystal removal, and mixing between cogenetic magmas. Crystallization of $\mathrm{Rb}$ and $\mathrm{Sr}$ bearing phases after the initial differentiation even may cause the crystals and/or the glass phase to lie off the isochron depending on the volumetric significance of the new phases, but will not disturb the position of the whole rock with respect to an isochron defined by a suite of whole-rock samples, as long as the crystals are not removed. Isochronous arrays like those described in this paper cannot be produced by mixing of unrelated magmas. Although contamination might produce a crude apparent isochron (c.f. [35]), the age defined by the isochron would not be expected to correlate with any geologic event. This contrasts with the case of Glass Mountain, in which the isochron ages correspond to the oldest eruptions in a given area.

\section{Other evidence bearing on isochronous relation- ships between magmas}

Independent of the isochronous relationship, we can assess whether there have been changes in $\mathrm{Rb} / \mathrm{Sr}$ and $\mathrm{Sr}$ concentration in the magma since the initial differentiation by examining the variations with time of these parameters. The $\mathrm{Rb} / \mathrm{Sr}$ ratios and $\mathrm{Sr}$ concentrations for the older lavas do not display any systematic relationship with eruption age, whether the older lavas are considered as a whole or if each isochronous group is considered separately. In fact, the $\mathrm{Sr}$ concentrations and $\mathrm{Rb} / \mathrm{Sr}$ ratios of adjacent lavas erupted at different times in some instances are identical. This is true for units YA and YE (2.32 and $2.31 \mathrm{ppm})$, YO and YK (1.19 and $1.23 \mathrm{ppm})$ and $\mathrm{OJ}$ and $\mathrm{OK}$ ( 0.17 and $0.16 \mathrm{ppm}$ ), even though in each case the lavas erupted at least 100,000 years apart. Thus, there is no indication that the magmas differentiated progressively with respect to $\mathrm{Rb} / \mathrm{Sr}$ over $10^{5}$-year intervals during protracted residence in the magma reservoir. This is consistent with the $\mathrm{Rb}-\mathrm{Sr}$ isotopic evidence that most crystallization of feldspar took place in discrete events, rather than progressively.

\section{Implications of inherited isochrons for the evolution of the Long Valley magmatic system}

It is difficult to escape the conclusion that the $\mathrm{Rb}-\mathrm{Sr}$ isochrons for the Glass Mountain lavas date the time of major differentiation of the magmas. The implications of this are considerable and in some instances difficult to reconcile with popular models for the evolution of silicic magmatic systems.

\subsection{Residence times of silicic magmas}

Assuming that the $\mathrm{Rb}-\mathrm{Sr}$ isochron ages date the differentiation of the magmas, the minimum longevity of the magmas in the chamber can be determined from the difference between the isochron age and the eruption age of the last magma erupted from that system. On this basis, at least three separately differentiated magmas appear to have persisted in the crust under Long Valley for minimum durations of $0.7 \mathrm{~m} . \mathrm{y}$. (for the inner older lavas), 0.5 m.y. (for outer older lavas) and $0.3 \mathrm{~m} . \mathrm{y}$. (for outer younger lavas). This requires a 
mechanism for keeping these evolved magmas hot for long periods. Thermal modeling of pluton-sized silicic magma bodies thousands of cubic kilometers in volume suggests that they would solidify through conductive heat loss through the chamber walls over periods of $10^{4}-10^{5}$ years $[43,44]$. If this is the case, it is necessary to invoke a flux of heat from depth that maintains the magmas above their solidus. This is not an unreasonable suggestion, as intrusion of the crust by mantle-derived basalt has long been regarded by many as the principal mechanism for the generation of sizeable volumes of silicic magma (e.g., [6,13,14,16,19,45]). However, the feasibility of maintaining large rhyolitic magma bodies at high levels in the crust for long periods by this mechanism has been questioned by Huppert and Sparks [19]. While there is no doubt that long-lived rhyolitic magma systems exist (e.g., $[1,15,21,23,46])$, Huppert and Sparks suggest that this may reflect repeated melting of the deep crust, rather than episodic tapping of a high-level chamber which, they suggest, could be a relatively transient phenomenon. The $\mathrm{Rb}-\mathrm{Sr}$ isochrons for the precaldera rhyolites of Long Valley are inconsistent with this model (although saying nothing about other silicic systems). The data make sense only in terms of a long-lived, highly differentiated system.

The magma batches that share an isochronous relationship did not exist as high- $\mathrm{Rb} / \mathrm{Sr}$ magmas until the times defined by the isochrons. That is the isochrons do not merely date the time of generation of a range of $\mathrm{Rb} / \mathrm{Sr}$ ratios (i.e., internal differentiation) but also the time of their generation as high- $\mathrm{Rb} / \mathrm{Sr}$ magmas. The evidence for this is as follows: the initial ${ }^{87} \mathrm{Sr} /{ }^{86} \mathrm{Sr}$ ratios of the two hypothesized magma batches at the time of their emplacement are identical (0.706). Each appears to have (albeit only as sampled) average $\mathrm{Rb} / \mathrm{Sr}$ ratios of roughly 500 . In the period between 2.09 and $1.90 \mathrm{Ma}$, the weighted ${ }^{87} \mathrm{Sr} /{ }^{86} \mathrm{Sr}$ ratios of such evolved magmas should have increased from 0.706 to greater than 0.710 . The implication is that the magmas defining the $1.9-\mathrm{Ma}$ isochron with an initial ${ }^{87} \mathrm{Sr} /{ }^{86} \mathrm{Sr}$ of $0.706 \mathrm{did}$ not exist in an evolved form until $1.9 \mathrm{Ma}$; that is, $1.90 \pm 0.02 \mathrm{Ma}$ dates not only the time of internal differentiation of the layer, but also the time of differentiation from a less-evolved magma (with $\mathrm{Rb} / \mathrm{Sr}$ less than 100 ), probably concomitant with emplacement into the upper reaches of the magma chamber.

\subsection{Major crystallization and differentiation in discrete events}

Intuitively, one would expect that consequences of the continued heating of a silicic magma system by intrusion of mantle-derived magmas would include large-scale convection and assimilation of more crustal material at the roofs and walls, followed eventually by progressive crystallization of the convecting silicic magmas from the margins inwards (e.g., $[9,20,45,47,48])$. The data for Glass Mountain do not fit such a model. The isochronous relationships require that crystallization of low- $\mathrm{Rb} / \mathrm{Sr}$ phases (such as sanidine and plagioclase) takes place in discrete events probably associated with magma emplacement. On reflection, this is perhaps not so surprising; the most drastic crystallization and differentiation is expected during relatively rapid cooling that would accompany emplacement into cold crust. However, the data also suggest that virtually no major crystallization of $\mathrm{Sr}$ - or Rb-rich phases takes place after this time.

\subsection{The nature of magma convection}

A further implication of the $\mathrm{Rb}-\mathrm{Sr}$ isotopic data is that magma within the chamber must convect in separate layers or cells, with little mass transfer between them. The very existence of two different $\mathrm{Rb}-\mathrm{Sr}$ isochrons defined by the older lavas from different regions requires that there was no mixing between the magmas tapped in these two regions. In addition, the mode of convective heat transfer must not result in homogenization of the magmas that share an isochronous relationship; although an isochron can survive mixing between comagmatic liquids (Fig. 5), mixing must not be so extensive as to eliminate the range in $\mathrm{Rb} / \mathrm{Sr}$ ratio that is the basis of the isochron.

\subsection{The change in the Long Valley magma} system at $1.2 \mathrm{Ma}$

Metz and Mahood [22,27] interpreted the relative chemical and mineralogical homogeneity of the younger Glass Mountain lavas as reflecting eruptions from a large integrated upper crustal magma chamber that coalesced by $1.2 \mathrm{Ma}$, and 
they suggested on the basis of incompatible element abundances that the younger lavas contained a smaller crustal component than the older lavas. The Nd isotopic data presented here are fully compatible with a model of mixing of mantle-derived components with crust-derived components at about 1.2 Ma. The Sr contents of the rhyolites are so low that ${ }^{87} \mathrm{Sr} /{ }^{86} \mathrm{Sr}$ ratios (and $\mathrm{Sr}$ concentrations) would be unusually sensitive to additions of mantle-derived components if mixing took place between magma like the older lavas and intermediate or mafic magmas. The $\mathrm{Sr}$ isotopic composition of the new mixed magmas would be essentially identical to that of the more mafic magma. Three basalts in the vicinity yield ${ }^{87} \mathrm{Sr} /{ }^{86} \mathrm{Sr}$ ratios of $0.7059,0.7060$, and 0.7062 ([31]; D. Ormerod, personal communication, 1988). These values are in agreement with the initial ${ }^{87} \mathrm{Sr} /{ }^{86} \mathrm{Sr}$ ratios for the Glass Mountain magmas when emplaced in the magma chamber, as deduced from the isochron intercepts $(0.7060 \pm 3$, $0.7063 \pm 4$, and $0.7061 \pm 3$ ). Hence it appears that nearly all the $\mathrm{Sr}$ in these high-silica rhyolites could be mantle-derived. Clearly the fact that the erupted $\mathrm{Sr}$ isotopic compositions of the post-1.2-Ma lavas (and the Bishop Tuff) are relatively uniform (apart from alteration in the case of the Bishop Tuff) despite a wide range in $\mathrm{Sr}$ content (Fig. 2) indicates that the last addition of mantle-derived components preceded the differentiation that resulted in the range of fractionated $\mathrm{Rb} / \mathrm{Sr}$ ratios observed; otherwise there would be a correlation between ${ }^{87} \mathrm{Sr} /{ }^{86} \mathrm{Sr}$ and $1 / \mathrm{Sr}$. However, the magmas must have already been quite differentiated prior to the last addition of mantle-derived $\mathrm{Sr}$ in order that the latter dominated the $\mathrm{Sr}$ isotopic compositions. The $\mathrm{Pb}$ concentrations of the rhyolites are sufficiently high that the isotopic composition of the parent magma is buffered against the effects of adding mantle-derived $\mathrm{Pb}$, which is invariably present in low concentrations in basalt. The Nd concentrations of the rhyolites, the crust, and basalts are commonly of the same order of magnitude. The variations in the $\mathrm{Nd}$ isotopic data, therefore, probably reflect most directly the mixing of crust- and mantle-derived components in differing proportions. The only possible mechanism for adding mantle-derived components into a rhyolite system would be in a relatively evolved state (c.f. [13]), possibly after interaction with the deep crust and deeper parts of the melt zone, all of which had approximately uniform $\mathrm{Pb}$ isotopic composition. Although it could be argued that the older lavas represent the more contaminated roof zone of a single body that included the magma erupted as the younger lavas, the $\mathrm{Pb}$ isotopic composition of which is dominated by input of $\mathrm{Pb}$ from a relatively uniform crust, the addition of mantle-derived components at $1.2 \mathrm{Ma}$ is the preferred hypothesis because the $\mathrm{Rb}-\mathrm{Sr}$ isochron age of $1.14 \pm 0.08 \mathrm{Ma}$ for the younger lavas is a direct indication that the $\mathrm{Sr}$ isotopic systematics of the magmas were totally homogenized and "reset" at this time. The implication is that there was large-scale turnover and mixing in the magma chamber shortly after $1.2 \mathrm{Ma}$. The observed increase in volumetric rate of eruption after $1.2 \mathrm{Ma}$ [22] would also be explained by a new, major input of magma.

\subsection{The younger lavas of Glass Mountain and the genesis of the Bishop Tuff \\ Magma with the same isotopic signature as the} Bishop Tuff can clearly be identified back to 1.2 $\mathrm{Ma}$, that is, 500,000 years prior to eruption of the Bishop Tuff itself. The new magma formed at about 1.2 Ma immediately developed a highly evolved roof zone which was tapped during eruption of the younger lavas. Although evolved magma was present by $1.1 \mathrm{Ma}$, this does not necessarily mean that the magma was static between this time and when the Bishop Tuff was erupted at $0.73 \mathrm{Ma}$. It merely means that an isotopically homogeneous magma had been established which may have continued to convect and differentiate. Contamination by materials such as congealed margins, roof rocks, and injected basalt must have been minimal in order to maintain the uniform $\mathrm{Nd}$ and $\mathrm{Sr}$ isotopic compositions.

The $\mathrm{Rb}-\mathrm{Sr}$ isochron age of $1.14 \pm 0.08 \mathrm{Ma}$ defined by four of the younger lavas suggests that at least a part of the newly reorganized magma chamber differentiated early. Although the data presented here do not establish over what period the Bishop Tuff magma differentiated, they do indicate that crystallization and differentiation of the earlier Long Valley high-silica rhyolites was not a protracted gradual process, hut rather was extremely rapid, resulting in highly differentiated roof zone magmas within less than about $10^{4}$ 
years of magma emplacement. It is therefore conceivable that the Bishop Tuff magma differentiated in a similar manner at $1.2 \mathrm{Ma}$ along with the magma represented by the younger Glass Mountain lavas. Such a scenario is as envisioned by Christensen and DePaolo [30], who argued on the basis of $\mathrm{Sr}$ isotope data for the Bishop Tuff that the upper and lower parts of the magma differentiated into separate parts about 0.5 m.y. prior to eruption at $0.73 \mathrm{Ma}$. The combined data from these two studies are therefore compatible with the view that $1.2 \mathrm{Ma}$ was the time of major remixing and rapid differentiation of the magmas that were subsequently erupted as the younger Glass Mountain lavas and the Bishop Tuff. The data are not inconsistent with the possibility of further minor differentiation between 1.2 and 0.73 Ma. Indeed, this is one explanation for the differences in chemistry between the youngest Glass Mountain lavas and the earliest-erupted Bishop Tuff [27].

\section{Summary}

Figure 6 presents a speculative model for the evolution of the Long Valley magmatic system that is consistent with the isotopic data presented here. We emphasize that other interpretations are possible. For example, rather than the magma layers presented in Fig. 6, two separate magma bodies or isolated cupolas on a larger chamber could also satisfy the observed relation between location and isochron age of the older lavas. We have portrayed the differentiation event that imposes the isochrons on the magmas as being associated with emplacement of felsic magmas as layers near the roof of the chamber. It is also possible that crystallization and differentiation results from "pressure-quenching" upon major eruptions of magma that was already near the chamber roof (but had $\mathrm{Rb} / \mathrm{Sr}<100$ to preclude in-situ decay from raising the ${ }^{87} \mathrm{Sr} /{ }^{86} \mathrm{Sr}$ ratio secularly).

In the model presented in Fig. 6, the fact that the rocks included on the two isochrons for the older lavas are spatially related to the position of the caldera is taken to suggest that the regions tapped were (like the ring fault) controlled in part by the geometry of the magma chamber. The spatial pattern is interpreted as reflecting the intersection of horizontally stratified magma layers with a domical chamber roof. The uppermost layer (sampled by the lavas defining the 2.1-Ma isochron) consists of magma that differentiated at 2.1 $\mathrm{Ma}$ when it was emplaced at the roof of the
2.I $\mathrm{Ma}$

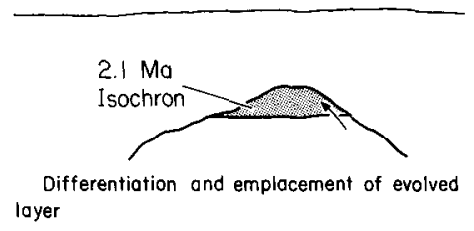

$1.9-1.4 \mathrm{Ma}$

(d)

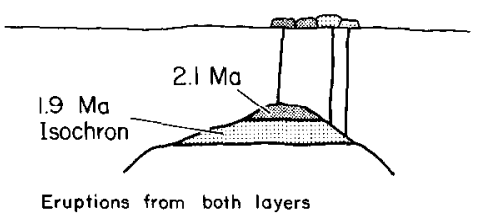

$2.1-1.9 \mathrm{Ma}$

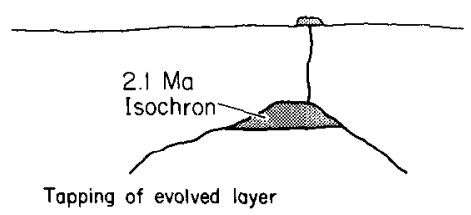

$1.4-1.2 \mathrm{Ma}$

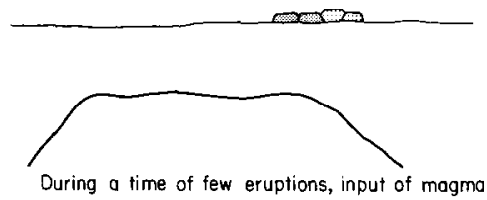

During a time of few eruptions, input of magma
with a greater mantle-derived component leads to growth of chamber and lorge-scale mixing of phyolitic mogmas
$1.9 \mathrm{Mo}$

(c)

Fig. 6. A series of schematic sketches illustrating one possible scenario, consistent with the isotopic data presented here, for the evolution of the upper reaches of the Long Valley magma chamber. See text for discussion. 
chamber. The layer below this (sampled by the lavas defining the $1.9-\mathrm{Ma}$ isochron) was formed during a later differentiation event upon emplacement in that region. A series of fractures tapped the magma through the roof, the intersection of the roof with the magma layers resulting in the upper (2.1-Ma) layer being tapped closer to the center of the chamber and the lower (1.9-Ma) layer being tapped farther out.

There are few dated Glass Mountain lavas with ages between 1.4 and 1.2 Ma. During this period when the chamber lost little material to eruption, a new input of magma with a large mantle component led to large-scale mixing in the chamber and isotopic homogenization of the magma. Differentiation closely followed this event, as recorded in the 1.1-ma isochron for four of the younger lavas. The similarity in isotopic and chemical composition of the younger lavas and the Bishop Tuff indicate that the magma ultimately erupted in the catastrophic, explosive eruption at $0.73 \mathrm{Ma}$ was present in the magma chamber by $1.1 \mathrm{Ma}$.

Given the evidence outlined above for a relationship between magma eruption time, magma differentiation, and perhaps magma emplacement, it is worth briefly speculating on the possibilities of cause and effect in the system. The suggestion has been made by several authors that marginal upwelling of gravitationally unstable evolved magmas is a possible mechanism for the vertical zoning of some high-silica rhyolite magmas (e.g., [43]). The implication of the evidence that two highly evolved layers were differentiated and emplaced separately at 2.1 and $1.9 \mathrm{Ma}$ at Long Valley is that the magmatic system was somehow capable of repeatedly producing highly evolved liquids. In Fig. 6 we illustrate our expectation that other layers were formed at depth in the magma chamber, but were never tapped by the older lavas because they were at too great a depth. It seems possible that these magmas had some critical buoyancy which resulted in their emplacement at the top of the chamber whenever they were produced. Alternatively, they may have simply differentiated from low- $\mathrm{Rb} / \mathrm{Sr}$ magmas en route to the surface. If buoyant layers of differentiated magma rise to near the surface, it is likely that the instability itself or the expansion of an exsolving vapor phase could induce volcanic eruptions, resulting the effects we observe.

\section{Acknowledgements}

This is the first publication of data from the new Radiogeneic Isotope Geochemistry Laboratory (RIGL) at the University of Michigan. A.N.H. acknowledges with gratitude the encouragement and financial support of the Department of Geological Sciences, University of Michigan, the Shell Foundation, and the National Science Foundation. This work has been supported by N.S.F. grants EAR 8616061 and EAR 8720564 to A.N.H. and RI8800088 to G.A.M. and by the Turner Fund of the University of Michigan. A.N.H. also thanks the many colleagues both internal and external who have helped in practical ways with the establishment of RIGL. We are grateful to J. Hutchinson, F. McLaren and D.L.-C. Lee for laboratory assistance. The critical comments of C.R. Bacon, S. Galer, and R. Carlson improved an earlier version of the script.

\section{References}

1 R.A. Bailey, G.B. Dalrymple and M.A. Lanphere, Volcanism, structure and geochronology of Long Valley caldera, Mono County, California, J. Geophys. Res. 81, 725-744, 1976

2 C.D. Miller, Holocene eruptions at the Inyo volcanic chain, California: implications for possible eruptions in Long Valley caldera, Geology 13, 14-17, 1985.

$3 \mathrm{~W}$. Hildreth, The Bishop Tuff: evidence for the origin of compositional zonation in silicic magma chambers, Geol. Soc. Am. Spec. Pap. 180, 43-75, 1979.

4 P.J. Michael, Chemical differentiation of the Bishop Tuff and other high-silica magmas through crystallisation processes, Geology 11, 31-34, 1983

5 K.L. Cameron, Bishop Tuff revisited: new rare earth element data consistent with crystal fractionation, Science 224, 1338-1340, 1984

6 D.J. DePaolo, A neodymium and strontium isotopic study of the Mesozoic calc-alkaline granitic batholiths of the Sierra Nevada and Peninsular Ranges, California, J. Geophys. Res. 86, 10470-10488, 1981.

7 A.N. Halliday, Coupled $\mathrm{Sm}-\mathrm{Nd}$ and U-Pb systematics in late Caldonian granites and the basement under northern Britain, Nature 307, 229-233, 1984.

8 A.N. Halliday, W.E. Stephens, R.H. Hunter, M.A. Menzies, A.P. Dickin and P.J. Hamilton, Isotopic and chemical constraints on the building of the deep Scottish lithosphere, 150th Anniv. Geol. Soc. Edinburgh Spec. Issue, Scott, J. Geol. 21, 465-491, 1985.

9 D.B. Clarke, A.N. Halliday and P.J. Hamilton, Neodymium and strontium isotopic constraints on the origin of the peraluminous granitoids of the South Mountain batholith, Nova Scotia, Canada, Isot. Geosci. 9, 15-24, 1988. 
10 A.P. Dickin, A.E. Fallick, A.N. Halliday, R.M. Macintyre and W.E. Stephens, An isotopic and geochronologic study of the younger igneous rocks of the Seychelles, Earth Planet. Sci. Lett. 81, 46-56, 1986.

11 A.N. Halliday, W. Hildreth, R. Christiansen and F. MacLaren, Fine resolution of crustal contamination in the Yellowstone Plateau volcanic field, Terra Cognita 6 , 198-199, 1986.

12 A.N Halliday, A.E. Fallick, J. Hutchinson and W. Hildreth, $\mathrm{A} \mathrm{Nd}, \mathrm{Sr}$ and $\mathrm{O}$ isotopic investigation into the causes of chemical and isotopic zonation in the Bishop Tuff, California, Earth Planet. Sci. Lett. 68, 379-391, 1984.

13 G.A. Mahood and A.N. Halliday, The generation of highsilica rhyolite: a Nd, Sr, and O isotopic study of Sierra La Primavera, Mexican Neovolcanic Belt, Contrib. Mineral. Petrol. 77, 129-149, 1988.

14 P.E. Holden, A.N. Halliday and W.E. Stephens, Neodymium and strontium isotope content of microdiorite enclaves points to mantle input to granitoid production, Nature 330, 53-56, 1987.

15 R.L. Smith, Ash flow magmatism, Geol. Soc. Am. Spec. Pap. 180, 5-28, 1979.

16 W. Hildreth, Gradients in silicic magma chambers: implications for lithospheric magmatism, J. Geophys. Res. 86, 10153-10192, 1981.

17 C.R. Bacon, R. Macdonald, R.L. Smith and P.A. Baedecker, Pleistocene high-silica rhyolites of the Coso volcanic field, Inyo county, California, J. Geophys. Res. 86, 10223-10241, 1981.

18 G.A. Mahood, Chemical evolution of a Pleistocene rhyolite center: Sierra La Primavera, Jalisco, Mexico, Contrib. Mineral. Petrol. 77, 129-149, 1981.

19 H.E. Huppert and R.S.J. Sparks, The generation of granitic magmas by intrusion of basalt into continental crust. $J$. Petrol. 29, 599-624, 1988.

20 C.R. Bacon, H. Kurasawa, M.H. Delevaux, R.W. Kistler and B.R. Doe, Lead and strontium isotopic evidence for crustal interaction and compositional zonation in the source regions of Pleistocene basaltic and rhyolitic magmas of the Coso volcanic field, California, Contrib. Mineral. Petrol. 85, 366-375, 1984.

21 W. Hildreth, R.L. Christiansen and J.R. O'Neil, Catastrophic isotopic modification of rhyolitic magma at times of caldera subsidence, Yellowstone plateau volcanic field, J. Geophys. Res. 89, 8339-8369, 1984.

22 J.M. Metz and G.A. Mahood, Precursors to the Bishop Tuff eruption: Glass Mountain, Long Valley, California, J. Geophys. Res. 90, 11121-11126, 1985.

23 E.A. Mankinen, C.S. Gromme, G.B. Dalrymple, M.A. Lanphere and R.A. Bailey, Paleomagnetism and $\mathrm{K}-\mathrm{Ar}$ ages of volcanic rocks from Long Valley caldera, California, J. Geophys. Res. 91, 633-652, 1986.

24 J.M. Metz and R.A. Bailey, Geologic map of Glass Mountain, Long Valley, California, U.S. Geol. Surv., Map, in press.

25 C.D. Rinehart and D.C. Ross, Geology and mineral deposits of the Mount Morrison quadrangle, Sierra Nevada, California, with a section on a gravity study of Long Valley by L.C. Pakiser, U.S. Geol. Surv., Prof. Pap. 385, 104 p., 1957.

26 N.K. Huber, C.D. Rinehart, Geologic map of the Devil's
Postpile quadrangle, Sierra Nevada, California, U.S. Geol. Surv., Map GQ-437, 1965.

27 J.M. Metz and G.A. Mahood, Development of the Long Valley magma chamber recorded in precaldera rhyolite lavas of Glass Mountain, Contrib. Mineral. Petrol., in press.

28 J.M. Metz, Physical and chemical evolution of Glass Mountain: precaldera high-silica rhyolites from the Long Valley magma system, 161 pp., Ph.D. Thesis, Stanford University, 1987 (unpublished).

29 P. Richard, N. Shimizu and C.J. Allègre, ${ }^{143} \mathrm{Nd} /{ }^{146} \mathrm{Nd}$, a natural tracer: an application to ocean basalts, Earth Planet Sci. Lett. 31, 269-278, 1976.

30 J.N. Christensen and D.J. DePaolo, Isotopic study of processes in a silicic magma chamber: the Bishop Tuff, Long Valley, California, EOS Trans. Am. Geophys. Union $68,434,1987$.

31 D.S. Ormerod, C.J. Hawkesworth, N.W. Rogers, W.P. Leeman and M.A. Menzies, Tectonic and magmatic transitions in the Western Great Basin, USA, Nature 333, 349-353, 1988.

32 S.M. Wickham, The segregation and emplacement of granitic magmas. J. Geol. Soc. London 144, 181-197, 1987.

33 R.W. Kistler and Z.E. Peterman, Variations in Sr, Rb, K, $\mathrm{Na}$, and initial ${ }^{87} \mathrm{Sr} /{ }^{86} \mathrm{Sr}$ in Mesozoic granitic rocks and intruded wall rocks in central California, Geol. Soc. Am. Bull. 84, 3489-3512, 1973.

34 W.P. Leeman and D.W. Phelps, Partitioning of rare earth and other trace elements between sanidine and coexisting volcanic glass. J. Geophys. Res. 86, 10193-10199, 1981.

35 D.R. Dickinson and I.L. Gibson, Feldspar fractionation and anomalous ${ }^{87} \mathrm{Sr} /{ }^{86} \mathrm{Sr}$ ratios in a suite of peralkaline silicic rocks, Geol. Soc. Am. Bull. 83, 231-240, 1972.

36 N.K. Mistra and V.S. Venkatasubramanian, Geochim. Cosmochim. Acta 41, 837-838, 1977.

37 G. Worner, H. Staudigel and A. Zindler, Isotopic constraints on open-system evolution of the Laacher See magma chamber (Eifel, West Germany), Earth Planet. Sci. Lett. 75, $37-49,1985$.

38 D.C. Noble and C.E. Hedge, ${ }^{87} \mathrm{Sr} /{ }^{86} \mathrm{Sr}$ variations within individual ash-flow sheets, U.S. Geol. Surv., Prof. Pap. 650-C, C133-C139, 1969.

39 R. Vollmer, K. Johnson, M.R. Giara, L. Lirer and R. Munno, Sr isotope geochemistry of megacrysts from continental rift and convergent plate margin alkaline volcanism in South Italy, J. Volcan. Geotherm. Res. 11, 314-327, 1981.

40 M. Cortini and P.W.C. van Calsteren, Lead isotope differences between whole-rock and phenocrysts in recent lavas from Southern Italy, Nature 314, 343-345, 1985.

41 D.J. Geist, J.D. Myers and C.D. Frost, Megacryst-bulk rock isotopic disequilibrium as an indicator of contamination processes: the Edgecumbe Volcanic Field, S.E. Alaska. Contrib. Mineral. Petrol. 99, 105-112, 1988.

42 C. Schuler and R.H. Steiger, On the genesis of feldspar megacrysts in granites: an Rb-Sr isotopic study, in Short Papers 4th Int. Conf. Geochron. Cosmochron. Isotope Geol., R.E. Zartman, ed., U.S. Geol. Surv., Open File Rep. 78-701, 386-387, 1978.

43 F. Spera, Thermal evolution of plutons: a parameterized approach, Science 297, 299-301, 1979. 
44 A.H. Lachenbruch, M.L. Sorey, R.E. Lewis and J.H. Sass, The near-surface hydrothermal regime of Long Valley caldera, J. Geophys. Res. 81, 763-784, 1976.

45 A.N. Halliday, W.E. Stephens and R.S.J. Harmon, Rb-Sr and $O$ isotopic relationships in 3 zoned Caledonian granitic plutons, southern Uplands, Scotland: evidence for varied sources and hybridization of magmas, J. Geol. Soc. London 137, 329-348, 1980.

46 P.W. Lipman, The roots of ash flow calderas in western
North America; windows into the tops of granitic batholiths, J. Geophys. Res. 89, 8801-8841, 1984.

47 R.S.J. Sparks, H.E. Huppert and F.R.S. Turner, The fluid dynamics of evolving magma chambers, Philos. Trans. R. Soc. London, Ser. A 310, 511-534, 1984.

48 S.M. Novak and G.A. Mahood, Rise and fall of a basalttrachyte-rhyolite magma system at the Kane Springs Wash caldera, Nevada, Contrib. Mineral. Petrol. 94, 352-373, 1986. 